\title{
Pengaruh Faktor Preferensi Bermukim Masyarakat dalam Memilih Hunian Perumahan terhadap Kondisi Fisik LingKungan di Pinggiran Selatan Kota Surakarta
}

\author{
Erlana Citra Putri Kharisma, Galing Yudana, Winny Astuti \\ Program Studi Perencanaan Wilayah dan Kota \\ Fakultas Teknik \\ Universitas Sebelas Maret, Surakarta \\ email: erlana.citra@gmail.com
}

\begin{abstract}
Limited land for housing in Surakarta eventually make the society chosen an alternative to living in residential housing on the southern fringe of Surakarta.The problems in this research is how influence of factors society living preference when choosing a residential housing to the physical condition of the environment on the southern fringe of Surakarta. The purpose of research is to find the influence of factors society living preference when choosing a residential housing to the physical condition of the environment on the southern fringe of Surakarta. The used research method was quantitative with deductive approach. The analysis technique used is descriptive eksplanatif analysis. Overall the conclusion of this research is factors society living preference when choosing a residential housing give high influence to physical condition of the environment on the southern fringe of Surakarta. When viewed its influence to each of these aspect physical condition of the environment, factors society living preference when choosing a residential housing give high level of influence on the residential density condition, give high level of influence on the facilities condition, give high level of influence on the infrastructure condition and give medium level of influence on the accessibility condition.
\end{abstract}

Keyword: Housing, Living preference, Physical condition of the environment

\section{PENDAHULUAN}

Keterbatasan lahan dan semakin adatnya suatu kota menjadikan daerah pinggiran sebagai alternatif pemecahan masalah. Menurut Djaldjoeni (1998) perubahan fisik perkotaan kearah luar menumbuhkan wilayah baru atau yang sering disebut sebagai daerah pinggiran. Selain itu daerah pinggiran kota memiliki daya tarik tersendiri yaitu menawarkan perumahan yang lebih luas. Menurut Burges dalam Ahmadi (2005) berkembangnya perumahan pada dasarnya bermula dari migrasi penduduk ke pusat kota dan kemudian secara alami menyebar ke pinggiran. Salah satu faktor yang mendorong pergerakan ke pinggiran kota adalah keinginan mendapatkan kehidupan yang alami, jauh dari polusi, nyaman dengan utilitas dan fasilitas yang terjamin. Memilih hunian perumahan di pinggiran kota, tiap-tiap orang memiliki kecenderungan tersendiri terhadap pilihannya. Kecenderungan untuk memilih tinggal dan tidak tinggal tersebut yang sering disebut dengan preferensi. Menurut Drabkin dalam Pratikto (2008) preferensi bermukim dalam memilih hunian perumahan bisa dikarenakan faktor aksesibilitas yaitu kemudahan dalam menjangkau lokasi menggunakan alat transportasi, kondisi lingkungan berkaitan dengan keadaan lingkungan fisik dan lingkungan sosialnya, kemudahan dalam menjangkau tempat kerja, tingkat pelayanan yang dapat dijangkau oleh masyarakat baik dari segi sarana maupun prasarananya. Dengan adanya kecenderungan orang memilih tempat tinggal karena faktor tertentu di pinggiran kota maka kemudian secara berkala terjadi pemusatan hunian perumahan, hal tersebut serta merta akan menciptakan perubahan kondisi fisik lingkungan secara perlahan (Miles, 2005).

Diketahui bahwa pinggiran Kota Surakarta bagian selatan masih menjadi favorit bagi masyarakat yang ingin bermukim (Joglosemar, 2010). Hal tersebut didasari karena kedekatan Surakarta bagian selatan yang masih dekat dengan pusat Kota Surakarta dan lebih banyak dibangun perumahan (Fitriastuti, 2010). Selain itu dilihat dari sisi kebijakan dalam Rencana Tata Ruang Wilayah Kota Surakarta 2011-2031 bahwa pemerintah Kota Surakarta mengarahkan pengembangan perumahan permukiman ke selatan. Dengan kondisi yang ada tersebut dalam sekejap 
fungsi perumahan kemudian beralih ke pinggiran Kota Surakarta bagian selatan dan memunculkan pertumbuhan perumahan yang baru.

Pada tahun 2000 telah banyak dibangun perumahan-perumahan yang berada Kecamatan Grogol dan Kecamatan Baki. Hal tersebut menjadi daya tarik bagi masyarakat yang memilih hunian perumahan di pinggiran selatan Kota Surakarta. Pada tahun 2000 kondisi fisik lingkungan terkait kepadatan hunian perumahan di pinggiran selatan Kota Surakarta masih menunjukkan kepadatan yang rendah. Akan tetapi di tahun 2016 kondisi fisik lingkungan terkait kepadatan hunian perumahan di pinggiran selatan Kota Surakarta telah mengalami peningkatan karena semakin meningkatnya pembangunan perumahan. Selain itu dilihat dari kondisi prasarana jaringan jalan, hingga tahun 2016 sudah terdapat perbaikan dan pembangunan jalan di beberapa ruas jalan. Dari kondisi tersebut terdapat dugaan bahwa faktor preferensi bermukim masyarakat dalam memilih hunian perumahan pinggiran kota memberikan pengaruh pada kondisi fisik lingkungan di pinggiran selatan Kota Surakarta pada saat ini. Rumusan masalah dalam penelitian ini adalah bagaimana pengaruh faktor preferensi bermukim masyarakat dalam memilih hunian perumahan terhadap kondisi fisik lingkungan pinggiran selatan Kota Surakarta.

\section{TINJAUAN PUSTAKA}

Tinjauan Pustaka ini menjadi dasar dalam penelitian yang diperlukan sebagai landasan teori yang kuat untuk kemudian dijadikan dasar dalam menentukan variabel penelitian, dan variabel tersebut akan digunakan sebagai dasar dalam menentukan kebutuhan data penelitian dan analisis.

\subsection{Karakter Pinggiran Kota}

1. Daerah pinggiran kota atau dalam bahasa inggrisnya disebut urban fringe, Smith dalam (Yunus, 1987) mendefinisikan sebagai suatu wilayah yang terletak pada lahan terbangun tetapi posisinya di luar batas administrasi kota. Pryor dalam (Yunus, 2008) menjelaskan bahwa daerah pinggiran kota atau urban fringe masih menjadi bagian yang berbatasan langsung dengan permukiman kota utama.

2. Menurut Phillips (dalam Harliani, 2013) proses pengkotaan ke daerah pinggiran terjadi ketika pusat kota sudah tidak dapat menampung kegiatan penduduk karena keterbatasan lahan. Proses pengkotaan ini biasanya diikuti dengan adanya pembangunan perumahan, perbaikan akses infrastruktur, serta perbaikan kualitas fisik dan lingkungan wilayah pinggiran kota.

3. Menurut Bourne (dalam Hanief, 2014) perubahan kondisi fisik yang terjadi di daerah pinggiran disebabkan karena perluasan batas kota, peremajaan di pusat kota, perluasan jaringan infrastruktur dan jaringan transportasi, tumbuhnya berbagai kegiatan industri, perumahan dan sarana rekreasi atau wisata.

4. Kawasan pinggiran kota memiliki karakteristik yang berbeda dengan pusat kota, menurut Dirjen Penataan Ruang (dalam Aditama, 2015) wilayah pinggiran kota memiliki kriteria kawasan sebagai berikut

a. Terdapat permukiman berskala kecil maupun besar dengan kepadatan campuran antara kepadatan tinggi dan rendah.

b. Harga lahan masih cenderung rendah.

c. Tersedia aksesibilitas berupa jaringan jalan menuju pusat kota.

d. Akses menuju kota inti/pusat kota masih terbatas.

\subsection{Faktor Preferensi Bermukim Pada Perumahan Pinggiran Kota}

Porteus (dalam Hidayati, 2014) menjelaskan preferensi bermukim memiliki arti kecenderungan seseorang dalam membuat keputusan untuk bermukim atau tidak, dan biasanya preferensi antara orang yang satu dengan orang yang lain berbeda-beda tergantung pada faktor-faktor penyebabnya.

1. Menurut Porteus (dalam Nursusandhari, 2009) beberapa kriteria yang dijadikan pertimbangan untuk memilih tempat tingga yaitu harga hunian, fasilitas, aksesibilitas.

2. Menurut Koestoer (dalam Ahmadi, 2000) keputusan keluarga dalam memilih lokasi tempat tinggal karena faktor kemudahan transportasi dan kedekatan dengan pusat kota.

3. Menurut Turner (dalam Hidayati, 2014) faktor yang dipertimbangkan dalam memilih hunian pinggiran kota karena harga rumah, pelayanan serta kenyamanan lingkungan.

4. Menurut Tarigan (dalam Aditama, 2015) faktor yang menyebabkan banyaknya yang memilih tinggal di perumahan pinggiran kota karena dipengaruhi aksesibilitas, 
ketersediaan sarana prasarana serta kenyamanan lingkungan.

5. Menurut Yusuf (2006) pilihan masyarakat memilih hunian perumahan di pinggiran kota didasari karena alasan biaya atau harga rumah yang ditawarkan cenderung murah. Dengan harga rumah yang relatif murah menjadikan daya tarik bagi masyarakat untuk memilih tinggal di pinggiran kota.

6. Menurut Wardana (2007) mengatakan bahwa aksesibilitas yang dekat dengan tempat kerja yang menjadikan masyarakat memilih hunian perumahan di daerah pinggiran kota.

\subsection{Kondisi Fisik Lingkungan Pinggiran Kota}

Lingkungan adalah segala sesuatu yang berada di sekitarnya baik berupa benda hidup, benda mati, benda nyata maupun abstrak, serta suasana yang terbentuk karena terjadinya interaksi (Mukono, 2000). Kondisi fisik lingkungan cenderung dinamis dan bisa dilihat dari kegiatan yang membentuknya.

Kondisi fisik lingkungan dalam hal ini cenderung pada perubahan secara kuantitas yang meliputi kondisi kepadatan hunian, kondisi sarana, kondisi prasarana, kondisi aksesibilitas pinggiran kota (Nurhadi, 2004).

Kondisi lingkungan perumahan pinggiran kota tersebut dipengaruhi oleh berbagai faktor diantaranya, kepadatan bangunan, sarana dan prasarana (Mukono, 2000).

Selain itu Catanese (1991) mengemukakan bahwa kualitas fisik lingkungan yang terjadi di lingkungan perumahan mengacu pada berbagai hal yang meliputi kualitas lingkungan fisik dan kualitas sistem pelayanan kota.

Kondisi lingkungan dilihat dari segi kualitas maupun kuantitasnya di kawasan perumahan maupun permukiman pinggiran kota, ditandai dengan kondisi kepadatan bangunan, kondisi sarana maupun prasarananya (Budiharjo, 1992).

\subsection{Pengaruh Preferensi Bermukim Pinggiran Kota Terhadap Kondisi Fisik Lingkungan Pinggiran Kota}

Miles (2005) mengatakan bahwa dengan adanya kecenderungan orang memilih tempat tinggal karena faktor tertentu di pinggiran kota maka kemudian secara berkala terjadi pemusatan hunian perumahan, hal tersebut serta merta akan menciptakan perubahan kondisi fisik lingkungan secara perlahan. Mayendra (2013) mengatakan bahwa preferensi dalam memilih hunian perumahan karena berbagai faktor akan berdampak positif dan berdampak negatif terhadap kondisi fisik lingkungannya. Berdampak positif bila preferensi terhadap hunian perumahan akan menjadikan peningkatan bagi pembangunan perumahan berserta sarana prasarana penunjangnya, namun preferensi terhadap hunian perumahan akan berdampak negatif bila dengan adanya pembangunan perumahan akan menjadikan kualitas air tanah di lingkungan menjadi buruk. Menurut Pratikto (2008) bahwa preferensi masyarakat dalam memilih hunian di batas luar kota atau di pinggiran kota akan memicu tumbuhnya perumahan baru. Dari tumbuhnya perumahan baru tersebut menjadi daya ungkit bagi penyediaan sarana, prasarana, peningkatan infrastruktur di daerah pinggiran kota. Selain itu menurut Nurhadi (2004) pembangunan perumahan mengikuti keinginan atau permintaan pasar, dalam hal ini berkaitan dengan kecenderungan masyarakat dalam memilih suatu hunian perumahan, secara berkala dengan semakin banyaknya pembangunan perumahan akan berpengaruh pada kondisi fisik lingkungannya.

\section{METODE PENELITIAN}

Metode penelitian ini berisi ruang lingkup penelitian, metode penelitian, variabel penelitian, teknik pengumpulan data, dan teknik analisis.

\subsection{Ruang Lingkup Penelitian}

\subsubsection{Ruang Lingkup Wilayah}

Ruang lingkup wilayah pada penelitian ini berada di pinggiran selatan Kota Surakarta yang terdiri dari 11 desa (Grogol, Madegondo, Kwarasan, Sanggrahan, Manang, Gentan, Gedangan, sebagian Siwal, sebagian Bakipandeyan, sebagian Kadilangu, dan sebagian Langenharjo). Penentuan lokasi tersebut berdasarkan proses deliniasi yang menggunakan justifikasi teori pinggiran kota, kebijakan, serta sebaran perumahan. Peta wilayah penelitian dapat dilihat di Lampiran 1.

\subsubsection{Ruang Lingkup Waktu}

Ruang lingkup waktu pada penelitian ini menggunakan tahun data dari tahun 2000 hingga 2016, hal tersebut didasari berdasarkan data yang didapat dari Dinas Pekerjaan Umum Kabupaten Sukoharjo bahwa giatnya pembangunan perumahan di pinggiran Kota Surakarta dilakukan sejak tahun 2000. Untuk identifikasi preferensi bermukim masyarakat 
yang menempati perumahan formal menggunakan data tahun 2000, sedangkan untuk identifikasi kondisi fisik lingkungan menggunakan tahun data 2000 hingga 2016.

\subsection{Metode Analisis}

Metode analisis yang digunakan dalam penelitian ini yaitu menggunakan metode pendekatan deduktif. Jenis penelitian yang digunakan dalam penelitian ini yaitu jenis penelitian kuantitatif.

\subsection{Variabel Penelitian}

Variabel digunakan untuk mendapatkan kebutuhan data, sehingga dari data yang ada dapat digunakan untuk analisis guna menjawab tujuan penelitian. Variabel dan indikator penelitian dapat dilihat pada Lampiran 2.

\subsection{Teknik Pengumpulan Data}

Teknik pengumpulan data yang dilakukan pada penelitian ini terbagi menjadi dua yaitu teknik pengumpulan data primer dan teknik pengumpulan data sekunder.

\subsection{Teknik Analisis}

Teknik analisis yang digunakan pada penelitian ini adalah menggunakan analisis deskriptif kuantitatif yang bersifat eksplanatif. Eksplanatif yang digunakan oleh peneliti karena ingin mengetahui mengapa situasi atau kondisi tertentu terjadi atau apa yang mempengaruhi terjadinya sesuatu. Pada penelitian ini mengunakan perhitungan kuantitatif dengan menggunakan skoring atau pembobotan pada variabel faktor preferensi bermukim dan variabel kondisi fisik lingkungan pinggiran kota. Setelah itu dilanjutkan dengan identifikasi pengaruh antara variabel faktor preferensi bermukim dengan variabel kondisi fisik lingkungan pinggiran kota dengan menggunakan tabel tingkat pengaruh.

\section{HASIL PENELITIAN}

Berdasarkan hasil analisis, faktor preferensi bermukim masyarakat dalam memilih hunian perumahan berpengaruh besar terhadap kondisi fisik lingkungan di pinggiran selatan Kota Surakarta.

\subsection{Faktor Preferensi Bermukim Masyarakat Dalam Memilih Hunian Perumahan Pinggiran Kota}

Pemilihan hunian perumahan yang ada di pinggiran selatan Kota Surakarta tentunya terdapat faktor-faktor yang dipertimbangkan pada saat pertama kali memilih hunian. Dari hasil identifikasi diketahui bahwa dari ke 5 variabel faktor preferensi bermukim dalam memilih hunian perumahan formal pinggiran kota yang terdiri dari faktor ketersediaan sarana, ketersediaan prasarana, aksesibilitas, kenyamanan lingkungan dan harga hunian, berdasarkan hasil kuesioner ke 5 faktor tersebut sangat dipertimbangkan pada saat memilih hunian perumahan di pinggiran selatan Kota Surakarta di tahun 2000. Masingmasing variabel memiliki skor yang berbeda beda, faktor ketersediaan sarana memiliki skor 2,58 , faktor ketersediaan prasarana memiliki skor 3, faktor aksesibilitas memiliki skor 2,38, faktor kenyamanan lingkungan memiliki skor 3 dan faktor harga hunian memiliki skor 3 . Akan tetapi ke 5 faktor tersebut masuk dalam kategori faktor yang sangat dipertimbangkan, sehingga masing-masing faktor memiliki skor 3. Dari hasil tersebut dapat diketahui bahwa preferensi masyarakat untuk bermukim sangat tinggi pada faktor-faktor yang sangat dipertimbangkan tersebut.

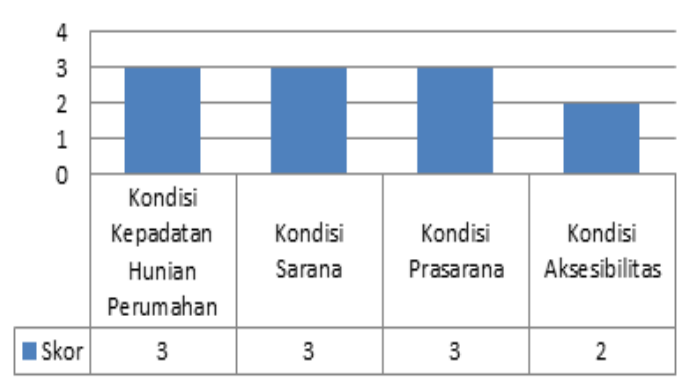

Gambar 1. Diagram Skor Faktor Preferensi Bermukim Pada Perumahan Pinggiran Kota tahun 2000

Preferensi bermukim masyarakat pada hunian perumahan di pinggiran selatan Kota Surakarta di tahun 2000 menjadi daya tarik tersendiri yang dibaca oleh para pengembang perumahan. Tingginya minat masyarakat terhadap perumahan pinggiran kota pada akhirnya akan menjadi daya ungkit pagi pembangunan perumahan pada lahan potensial di wilayah penelitian. Seperti yang dijelaskan oleh Budiharjo (1992) bahwa meningkatnya jumlah hunian unit perumahan, luasan perumahan di pinggiran kota lebih disebabkan karena preferensi masyarakat yang lebih memilih perumahan-perumahan baru di pinggiran kota yang didasari berbagai macam faktor seperti harga hunian yang relatif murah 
serta kedekatan dengan tempat kerja maupun pusat kota.

\subsection{Kondisi Fisik Lingkungan Pinggiran Selatan Kota Surakarta}

Berdasarkan hasil analisis dari masingmasing aspek kondisi fisik lingkungan seperti kondisi kepadatan hunian, kondisi sarana lingkungan, kondisi prasarana lingkungan, kondisi aksesibilitas, bahwa ke empat aspek tersebut di tahun 2016 mengalami peningkatan kondisi dari tahun tahun sebelumnya dilihat dari kuantitas atau jumlahnya. Berikut merupakan diagram skor kondisi fisik lingkungan setelah dilakukan analisis pada masing-masing aspek.

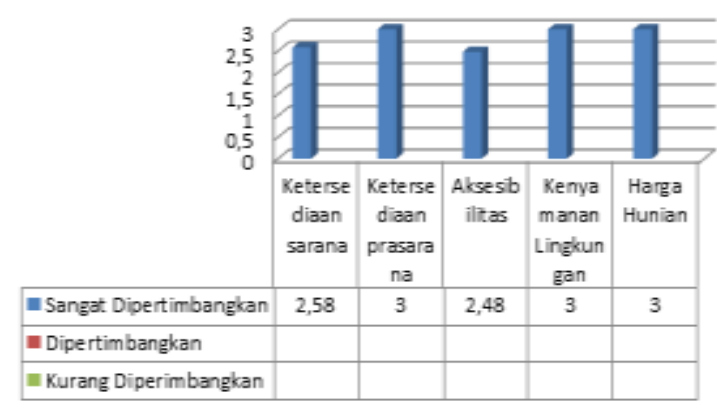

Gambar 2. Diagram Skor Kondisi Fisik Lingkungan Tahun 2016

Kondisi kepadatan hunian perumahan di tahun 2000 yang dilihat dari besarnya KDB (Koefisien Dasar Bangunan) perumahan menunjukkan angka $53,2 \%$ masuk dalam kategori sedang, kemudian di tahun 2016 besarnya KDB (Koefisien Dasar Bangunan) perumahan menunjukkan angka $62,65 \%$ masuk dalam kategori tinggi. Adanya peningkatan KDB (Koefisien Dasar Bangunan) perumahan tersebut, aspek kondisi kepadatan hunian mendapat skor 3. Kondisi sarana dan prasarana lingkungan pada tahun 2016 di wilayah penelitian mengalami peningkatan jumlah dan penggunaan dari tahun-tahun sebelumnya. Aspek kondisi sarana dan prasarana lingkungan masing-masing mendapat skor 3. Kondisi aksesibilitas berkaitan dengan pembangunan jaringan jalan baru, meningkatnya pembangunan jaringan jalan dapat diketahui dengan menggunakan indeks aksesibilitas. Indeks aksesibilitas di tahun 2000 menunjukkan angka sebesar 2,38 dan masuk dalam kategori sedang, sedangkan indeks aksesibilitas di tahun 2016 menunjukkan angka sebesar 3,61 dan masuk dalam kategori tinggi. Akan tetapi, dari ratarata perhitungan indeks aksesibilitas angka indeks aksesibilitas adalah 2,99 dan masuk dalam kategori sedang. Walaupun terjadi peningkatan pembangunan dan pembukaan jaringan jalan baru dalam kurun waktu enam belas tahun, akan tetapi indeks aksesibilitas masuk dalam kategori sedang. Kondisi aksesibilitas di wilayah penelitian adalah kondisi sedang dan mendapat skor 2 .

\subsection{Pengaruh Faktor Preferensi}

\section{Bermukim Masyarakat Dalam Memilih}

Hunian Perumahan Terhadap Kondisi Fisik Lingkungan Pinggiran Selatan Kota

\section{Surakarta}

Berdasarkan hasil analisis yang dilakukan dengan menggunakan tabel persilangan variabel, maka didapatkan hasil secara keseluruhan bahwa faktor preferensi bermukim masyarakat dalam memilih hunian perumahan berpengaruh besar pada kondisi fisik lingkungan pinggiran selatan Kota Surakarta. Berikut merupakan tabel persilangan antar variabel.

Tabel 1. Persilangan Antar Variabel

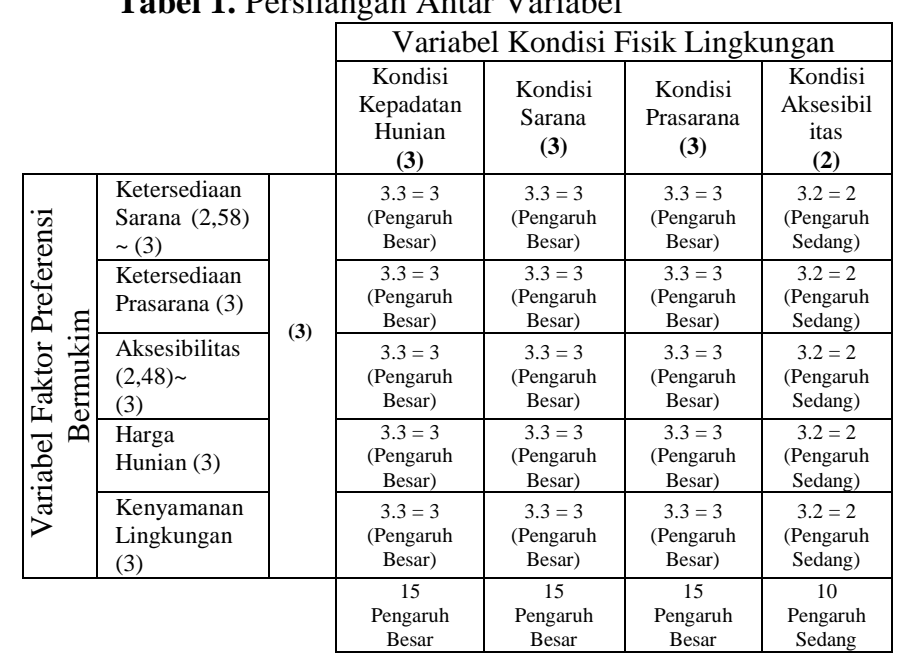

Pengaruh besar tersebut didapatkan dari hasil penjumlahan dari persilangan antar variabel. Pengaruh besar bernilai (3), pengaruh sedang bernilai (2), dan pengaruh kecil bernilai (1). Jumlah keseluruhan nilai pengaruh adalah berjumlah 55, angka tersebut masuk dalam klasifikasi pengaruh besar. Pengaruh tersebut secara langsung maupun tidak langsung, disebabkan karena tingginya preferensi bermukim masyarakat untuk menghuni perumahan pinggiran kota. Dari tingginya preferensi bermukim masyarakat untuk menghuni perumahan pinggiran kota, 
sehingga mendorong pihak pengembang untuk membangun perumahan-perumahan pada lahan-lahan potensial.

\subsection{Pengaruh Faktor Preferensi Bermukim Terhadap Kondisi Kepadatan Hunian Perumahan}

Berdasarkan analisis didapatkan hasil bahwa faktor preferensi bermukim berpengaruh besar terhadap aspek kondisi kepadatan hunian perumahan. Jumlah nilai pengaruh antara persilangan faktor preferensi bermukim dengan kondisi kepadatan hunian adalah 15 dan masuk dalam kriteria pengaruh besar. Preferensi bermukim masyarakat yang tinggi pada faktor-faktor yang sangat dipertimbangkan, menjadi daya ungkit bagi pengembang untuk membangun perumahanperumahan. Secara berkala hal tersebut akan mempengaruhi kondisi fisik lingkungannya pada aspek kondisi kepadatan hunian. Semakin meningkat jumlah perumahan, maka kepadatan perumahan juga semakin tinggi.

\subsection{Pengaruh Faktor Preferensi Bermukim Terhadap Kondisi Sarana Lingkungan}

Berdasarkan hasil analisis, diketahui bahwa faktor prefernsi bermukim berpengaruh besar pada kondisi sarana lingkungan. Jumlah nilai pengaruh antara persilangan faktor preferensi bermukim dengan kondisi sarana lingkungan adalah 15 dan masuk dalam kriteria pengaruh besar. Preferensi bermukim masyarakat yang tinggi pada faktor-faktor bermukim yang sangat dipertimbangkan, menjadi daya ungkit bagi pengembang untuk membangun perumahan-perumahan. Secara berkala hal tersebut akan mempengaruhi kondisi fisik lingkungannya pada aspek kondisi sarana lingkungannya, karena setiap adanya pembangunan perumahan terdapat juga pengadaan sarana penunjang. Jumlah sarana lingkungan pada tahun 2016 jumlahnya meningkat dari tahun tahun sebelumnya.

\subsection{Pengaruh Faktor Preferensi Bermukim Terhadap Kondisi Prasarana Lingkungan}

Berdasarkan hasil analisis diketahui bahwa faktor preferensi bermukim berpengaruh besar pada kondisi prasarana lingkungan. Jumlah nilai pengaruh antara persilangan faktor preferensi bermukim dengan kondisi prasarana lingkungan adalah 15 dan masuk dalam kriteria pengaruh besar. Preferensi bermukim masyarakat yang tinggi pada faktor-faktor bermukim yang sangat dipertimbangkan, menjadi daya ungkit bagi pengembang untuk membangun perumahan-perumahan. Secara berkala hal tersebut akan mempengaruhi kondisi fisik lingkungannya pada aspek kondisi prasarana lingkungan. Peningkatan kondisi prasarana lingkungan ditunjukkan dengan peningkatan jumlah dan penggunaan prasarana.

\subsection{Pengaruh Faktor Preferensi} Bermukim Terhadap Kondisi Aksesibilitas Berdasarkan hasil analisis diketahui bahwa faktor prefernsi bermukim berpengaruh sedang pada kondisi aksesibilitas. Jumlah nilai pengaruh antara persilangan faktor preferensi bermukim dengan kondisi aksesibilitas adalah 10 dan masuk dalam kriteria pengaruh sedang. Preferensi bermukim masyarakat yang tinggi pada faktor-faktor bermukim yang sangat dipertimbangkan, menjadi daya ungkit bagi pengembang untuk membangun perumahanperumahan. Secara berkala hal tersebut akan mempengaruhi kondisi fisik lingkungannya pada aspek kondisi aksesibilitas. Semakin meningkat jumlah perumahan yang dibangun tentunya semakin banyak jaringan jalan yang dibangun maupun diperbaiki, walaupun terjadi peningkatan panjang jaringan jalan dalam kurun waktu enam belas tahun yang ditunjukkan dengan indeks aksesibilitas akan tetapi berdasarkan perhitungan rata-ratanya indeks aksesibilitas masih dalam kategori sedang.

\section{KESIMPULAN}

Pengaruh faktor preferensi bermukim masyarakat dalam memilih hunian perumahan terhadap kondisi fisik lingkungan pinggiran selatan Kota Suarakarta, secara keseluruhan kondisi fisik lingkungan di pinggiran selatan Kota Surakarta terkena pengaruh.

Berdasarkan hasil analisis menggunakan tabel persilangan variabel diketahui secara keseluruhan bahwa pengaruh tersebut masuk dalam kriteria pengaruh besar. Akan tetapi bila dilihat pengaruhnya pada masing-masing aspek kondisi fisik lingkungan maka faktor preferensi bermukim masyarakat dalam memilih hunian perumahan memberikan pengaruh besar pada aspek kepadatan hunian perumahan, pengaruh besar pada aspek kondisi sarana lingkungan, pengaruh besar pada aspek prasarana lingkungan, dan pengaruh sedang pada aspek aksesibilitas. 
Secara langsung pengaruh tersebut didukung dengan semakin banyaknya pengembang perumahan yang membangun perumahan-perumahan formal di wilayah penelitian dari tahun ke tahun, sehingga secara berkala hal tersebut akan memberikan pengaruh bagi kondisi fisik lingkungannya yaitu dengan semakin meningkatnya kondisi kepadatan hunian perumahan, kondisi sarana lingkungan, kondisi prasarana lingkungan serta kondisi aksesibilitasnya.

Kondisi fisik lingkungan tersebut cenderung mendapat pengaruh positif dimana mengalami peningkatan dari segi kuantitas. Secara keseluruhan dapat disimpulkan bahwa faktor preferensi bermukim masyarakat dalam memilih hunian perumahan berpengaruh terhadap kondisi fisik lingkungan pinggiran selatan Kota Surakarta.

\section{REFERENSI}

Aditama,Kharisma

Narendra.2015. Karakteristik Pola Perjalanan Penduduk Pinggiran Menuju Kota Surakarta. Surakarta : UNS

Ahmadi,2005.Faktor-Faktor Yang Mempengaruhi Perkembangan Fisik Area Pinggiran Kota Berdasarkan Aspek Persepsi Bermukim Pada Kota Sengkang Propinsi Sulawesi Selatan. Semarang : Universitas Diponegoro

Budiharjo, Eko. 1992. Sejumlah Masalah Permukiman Kota. Bandung: Alumni

Catanese, Anthony J. 1991. Perencanaan Kota. Jakarta : Erlangga

Daldjoeni, N. 1998. Geografi Kota Dan Desa. Bandung : Alumni

Fitriastuti, Rachmadhani. 2010. Developer Bidik Daerah Pinggiran. Joglosemar. http://www.edisicetak.joglosemar.co/ber ita/developer-bidik-daerah-pinggiran6177.html. Diakses pada 15 Juni 2016

Harian Joglosemar. 2010. Perumahan Kabupaten Sukoharjo https://dok.joglosemar.co/rubrik/beritaharian/. Diakses pada 16 Mei 2016

Hanief, Farisul. 2014. Pengaruh Urban Sprawl Perubahan Bentuk Kota Semarang Ditinjai Dari Perubahan Kondisi Fisik Kelurahan Mateseh Kecamatan Tembalang. Semarang : Universitas Diponegoro

Harliani, Fanni. 2013. Urbanisasi di Pinggiran Kota, Waspadalah Dampak Negatif dari
Gentrifikasi.

http://www.kompasiana.com/fanniharlia ni/urbanisasi-di-pinggiran-kotawaspadalah-dampak-negatif-darigentrifikasi_552cb0816ea834374e8b45a 8. Kompasiana. Diakses pada 18 Agustus 2015

Hidayati, Masturina Kusuma. 2014. Faktor Yang Mempengaruhi Preferensi Bermukim Masyarakat Di Perumahan Kawasan Industri Kecamatan Jaten Kabupaten Karanganyar. Surakarta : UNS

Mayendra, Derry. 2013. Preferensi Bermukim Pinggiran Kota http://derrymayendra.blogspot.co.id/201 3/06/teori-preferensi-.html. Diakses pada 20 Juni 2016

Miles, Lee. 2005. Influence of Housing Preference. Blacksburg : Polytechnic Institute and State University

Mukono, H.J. 2000. Prinsip Dasar Kesehatan Lingkungan. Surabaya : Airlangga University Press

Nursusandhari, eva. 2009. Persepsi,preferensi, dan willingness to pay Masyarakat Terhadap Lingkungan Permukiman Sekitar Kawasan Industri. Bogor :Institut Pertanian Bogor

Nurhadi, I. 2004. Preferensi Konsumen Dalam Memilih Perumahan Pinggiran Kota. Bandung: Remaja Rosdakarya

Pratikto, H.H. 2008. Preferensi Konsumen Perumahan Terhadap Kondisi Fisik dan Ketersediaan Infrastruktur Pinggiran Kota. Yogyakarta : Gajah Mada Press

Rencana Tata Ruang Wilayah Kota Surakarta 2011-2031

Yunus, Hadi. 1987. Permasalahan Daerah Urban Fringe dan Alternatif Pemecahannya. Yogyakarta : Fakultas Geografi UGM

Yunus, Hadi. 2008. Dinamika Wilayah Peri Urban Determinan Masa Depan Kota . Yogyakarta: Pustaka Belajar.

Yusuf, Chandra. 2006. Perumahan Pinggiran Kota dan Dinamikanya. Bandung : Remaja Rosdakarya

Wardana, Wisnu. 2007. Perilaku Pengembang Dalam Pemilihan Lokasi dan Pembebasan Lahan Untuk Pembangunan Perumahan Sederhana. Yogyakarta : Andi Offset 


\section{LAMPIRAN 1}

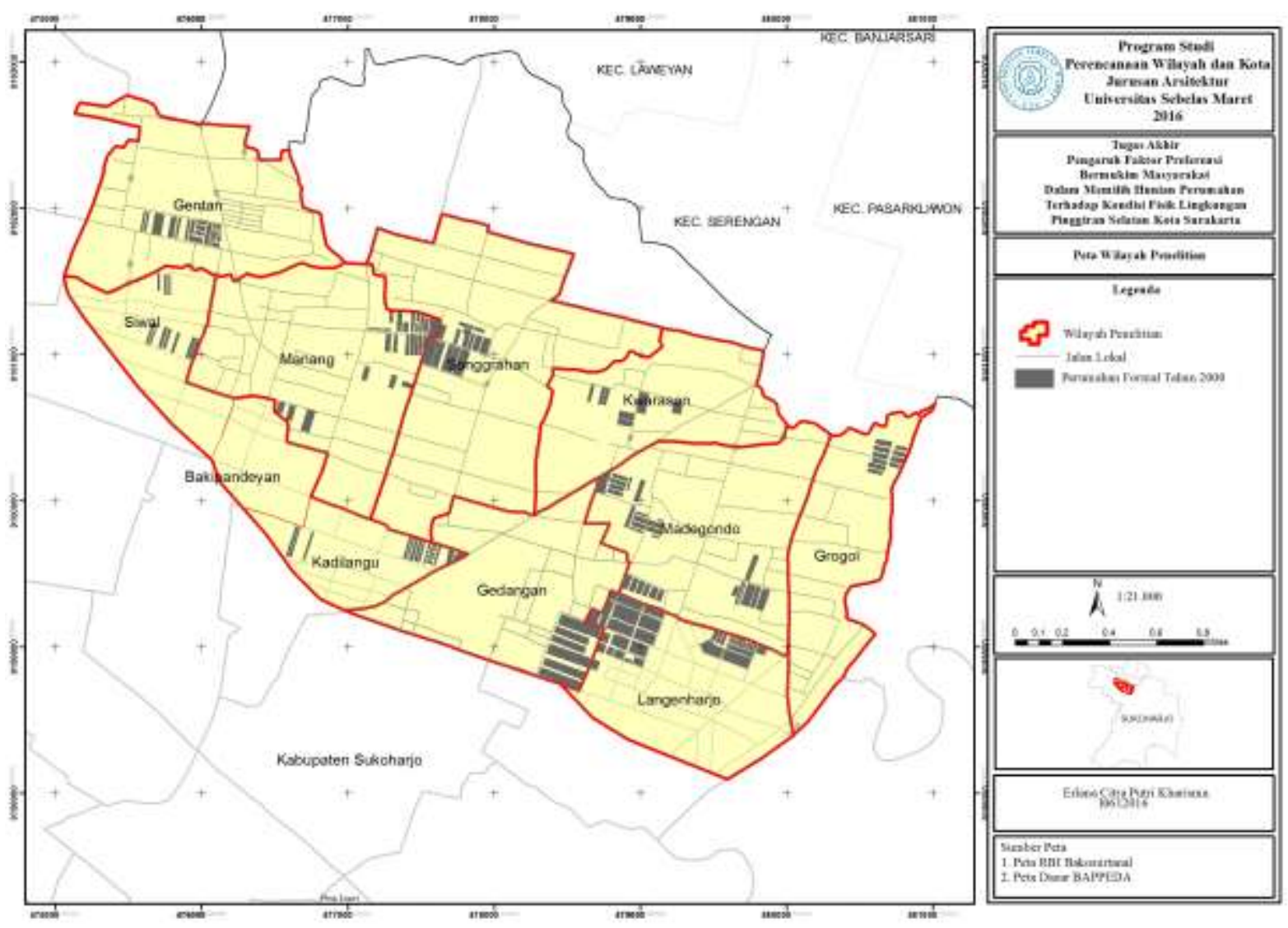

Gambar 3. Peta Wilayah Penelitian 


\section{LAMPIRAN 2}

\begin{tabular}{|c|c|c|c|c|c|}
\hline & Sasaran Penelitian & Sub Variahel & & Indikator & \\
\hline & sasaran Penelitian & Sub Variabel & 3 & 2 & 1 \\
\hline & & \begin{tabular}{|l|} 
Ketersediaan Sarana \\
-Sarana Pendidikan
\end{tabular} & $\begin{array}{l}\text { Sangat } \\
\text { tercukupi }\end{array}$ & $\begin{array}{l}\text { Cukup } \\
\text { Tercukupi }\end{array}$ & $\begin{array}{l}\text { Kurang } \\
\text { Tercukupi }\end{array}$ \\
\hline & & $\begin{array}{l}\text {-Sarana Perdagangan } \\
\text { - Sarana Kesehatan }\end{array}$ & $\begin{array}{l}\text { Sangat } \\
\text { tercukupi }\end{array}$ & $\begin{array}{l}\text { Cukup } \\
\text { Tercukupi }\end{array}$ & $\begin{array}{c}\text { Kurang } \\
\text { Tercukupi }\end{array}$ \\
\hline & & & $\begin{array}{c}\text { Sangat } \\
\text { tercukupi }\end{array}$ & $\begin{array}{l}\text { Cukup } \\
\text { Tercukupi }\end{array}$ & $\begin{array}{l}\text { Kurang } \\
\text { Tercukupi }\end{array}$ \\
\hline & & & $\begin{array}{l}\text { Sangat } \\
\text { tercukupi }\end{array}$ & $\begin{array}{l}\text { Cukup } \\
\text { Tercukupi }\end{array}$ & $\begin{array}{l}\text { Kurang } \\
\text { Tercukupi }\end{array}$ \\
\hline & & $\begin{array}{l}\text { Ketersediaan Prasarana } \\
\text {-Prasarana Jalan } \\
\text {-Prasarana Air }\end{array}$ & $\begin{array}{c}\text { Kondisi jalan } \\
\text { sangat baik }\end{array}$ & $\begin{array}{l}\text { Kondisi jalan } \\
\text { cukup baik }\end{array}$ & $\begin{array}{l}\text { Kondisi jalan } \\
\text { sebagian besar } \\
\text { rusak } \\
\end{array}$ \\
\hline & & -Prasarana Listrik & $\begin{array}{l}\text { Air bersih } \\
\text { memenuhi } \\
\text { kebutuhan }\end{array}$ & $\begin{array}{l}\text { Air bersih cukup } \\
\text { memenuhi } \\
\text { kebutuhan }\end{array}$ & $\begin{array}{c}\text { Air bersih } \\
\text { kurang mampu } \\
\text { memenuhi } \\
\text { kebutuhan }\end{array}$ \\
\hline $\begin{array}{l}\text { Variabel } \\
\text { Faktor }\end{array}$ & $\begin{array}{l}\text { Mengidentifiklasi } \\
\text { faktor preferensi }\end{array}$ & & $\begin{array}{l}\text { Listrik sangat } \\
\text { tercukupi }\end{array}$ & $\begin{array}{l}\text { Listrik cukup } \\
\text { tercukupi }\end{array}$ & $\begin{array}{l}\text { Listrik kurang } \\
\text { tercukupi }\end{array}$ \\
\hline $\begin{array}{l}\text { Bermukim } \\
\text { Pinggiran } \\
\text { Kota }\end{array}$ & $\begin{array}{c}\text { bermukim masyarakat } \\
\text { dalam memilih hunian } \\
\text { perumahan di } \\
\text { pinggiran kota }\end{array}$ & $\begin{array}{l}\text { Aksesibilitas } \\
\text { - Jarak ke pusat kota } \\
\text { - Jarak ke tempat kerja } \\
\text { - Kemudahan mendapat } \\
\text { transportasi umum } \\
\text { - Jarak ke pusat } \\
\text { pendidikan } \\
\text { - Jarak ke pusat } \\
\text { perdagangan } \\
\text { - Jarak ke pusat } \\
\text { kesehatan } \\
\text { - Jarak ke pusat } \\
\text { RTH/olahraga }\end{array}$ & $\begin{array}{l}\text { Sangat mudah } \\
\text { mencapai pusat } \\
\text { pelayanan } \\
\text { (dekat) }\end{array}$ & $\begin{array}{l}\text { Cukup mudah } \\
\text { mencapai } \\
\text { pelayanan } \\
\text { (sedang) }\end{array}$ & $\begin{array}{l}\text { Sulit mencapai } \\
\text { pusat pelayanan } \\
\text { (jauh) }\end{array}$ \\
\hline & & $\begin{array}{l}\text { Kenyamanan } \\
\text { Lingkungan } \\
\text {-Kebisingan } \\
\text {-Kualitas air } \\
\text {-Polusi udara } \\
\end{array}$ & Sangat nyaman & Cukup Nyaman & Kurang Nyaman \\
\hline & & Harga Hunian & Murah & Sedang & Mahal \\
\hline & Sasaran Penelitian & Sub Variabel & & Indikator & \\
\hline & Sasaran Penentian & Sub variabel & 3 & 2 & 1 \\
\hline & & $\begin{array}{l}\text { Kondisi Kepadatan } \\
\text { Hunian Perumahan }\end{array}$ & $\begin{array}{c}\text { klasifikasi } \\
\text { kepadatan tinggi } \\
(>60 \%)\end{array}$ & $\begin{array}{c}\text { klasifikasi } \\
\text { kepadatan } \\
\text { sedang } \\
(30 \%-60 \%) \\
\end{array}$ & $\begin{array}{l}\text { klasifikasi } \\
\text { kepadatan } \\
\text { rendah } \\
(0 \%-30 \%) \\
\end{array}$ \\
\hline Variabel & Mengidentifikasi & $\begin{array}{l}\text { Kondisi Sarana } \\
\text { Lingkungan }\end{array}$ & $\begin{array}{c}\text { Jumlah sarana } \\
\text { lingkungan } \\
\text { meningkat }\end{array}$ & $\begin{array}{c}\text { Jumlah sarana } \\
\text { lingkungan tetap }\end{array}$ & $\begin{array}{c}\text { Jumlah } \\
\text { sarana } \\
\text { lingkungan } \\
\text { berkurang } \\
\end{array}$ \\
\hline $\begin{array}{l}\text { Kondisi } \\
\text { Fisik } \\
\text { Lingkungan }\end{array}$ & $\begin{array}{c}\text { kondisi fisik } \\
\text { lingkungan pinggiran } \\
\text { selatan Kota Surakarta }\end{array}$ & $\begin{array}{l}\text { Kondisi Prasarana } \\
\text { Lingkungan }\end{array}$ & $\begin{array}{c}\text { Pertambahan } \\
\text { jumlah dan } \\
\text { penggunaan } \\
\text { prasarana } \\
\text { meningkat }\end{array}$ & $\begin{array}{c}\text { Pertambahan } \\
\text { jumlah dan } \\
\text { penggunaan } \\
\text { prasarana tetap }\end{array}$ & $\begin{array}{c}\text { Pertambahan } \\
\text { jumlah dan } \\
\text { penggunaan } \\
\text { prasarana } \\
\text { berkurang }\end{array}$ \\
\hline & & $\begin{array}{l}\text { Kondisi Aksesibilitas } \\
\text { Lingkungan }\end{array}$ & $\begin{array}{c}\text { Indeks } \\
\text { aksesibilitas } \\
3,46 \leq \mathrm{x} \leq 5,11\end{array}$ & $\begin{array}{c}\text { Indeks } \\
\text { aksesibilitas } \\
1,8 \leq \mathrm{x} \leq 3,45\end{array}$ & $\begin{array}{c}\text { Indeks } \\
\text { aksesibilitas } \\
0,05 \leq \mathrm{x} \leq \\
1,7 \\
\end{array}$ \\
\hline
\end{tabular}

